\title{
Taurolidine use as a Scolicidal Agent: We Need Different Methodologies
} Taurolidinin Skolisidal Ajan Olarak Kullanımı: Farklı Metodlara İhtiyacımız Var

\author{
Serkan Teksöz, Erman Aytaç
}

Department of General Surgery, Cerrahpaşa Faculty of Medicine, İstanbul University, İstanbul, Turkey

\section{Dear Editor,}

We have evaluated a thundering article entitled "The protoscolicidal effect of $1 \%$ polyvinylpyrrolidone-iodine (Pvp-I) and $2 \%$ taurolidine on abdominal hydatidosis" published by Ekci et al. in the Turkish Journal of Parasitology (1). The use of scolicidal agents is a sine qua non step in the interventional treatment of hydatid cyst in elective or emergent conditions. The current scolicidal or antihelminthic agents have major or minor side effects $(2,3)$. Scolicidal effectiveness causes increased toxicity. Studies are in progress to find less toxic and more effective scolicidal agent.

Taurolidine is a drug that has been used intravenously or intraperitoneally for the treatment of septic patients without causing side effects $(4,5)$. Taurolidine has antibacterial, antioxidant and antineoplastic properties. (6-9). The antioxidant effects of taurolidine could attenuate the immune response to the parasitic infections. Taurolidine also neutralizes bacterial endotoxins, exotoxins, and lipopolysaccharides (10-12). When the beneficial effects of taurolidine have been considered, evaluation of its effectivity against E. granulosus infection is a creative and original idea. Ekci et al. (1) had reported that Pvp-I had showed anti scolicidal activity in vitro and in vivo, but taurolidine was ineffective as a scolicidal agent. The method in the study evaluates contamination of the protoscolexes of E. granulosus after Pvp-I and taurolidine treatment rather than spontaneous rupture of the hydatid cysts into the abdominal cavity. The authors give the scolicidal treated protocolexes to the abdominal cavity. However, the original idea could be evaluated with a different meth- odology to reach a final decision about the scolicidal affectivity of taurolidine. Varying dosages of taurolidine and Pvp- I could be applied to a standardized number of the protoscolexes. The drugs could also been applied at different time periods. There is currently no consensus on the application time about any scolicidal agent. The effects of the applied dose of scolicidal agents should be evaluated with additional experimental groups without injecting protoscolex into the abdominal cavity of the animals by different application routes such as intraperitoneally or intravenously to observe the direct effects of taurolidine. Additional experimental groups could also be examined to evaluate the scolicidal activity of taurolidine in the animals infected with Echinococcus granulosus. Finally, statistical analysis, which had not been performed in this study, ought to be carried out to determine the real differences between the experimental groups. This leading report has an original aim, but further experimental studies must be designed on this topic to reach a definitive conclusion on the use of taurolidine for $E$. granulosus infection.

\section{REFERENCES}

1. Ekçi B, Gürol Y, Aydin I, Yalniz F, Ozcan M, Zengin K. The protoskolicidal effect of $1 \%$ polyvinylpyrrolidone-iodine (PVP-1) and $2 \%$ taurolidine on abdominal hydatidosis. Turkiye Parazitol Derg 2010; 34: 152-5.

2. Karayalcin K, Aras N. Kist hidatik cerrahisinde skolisidal madde kullanımı. T Klin J Surgery 1998; 3: 216-8.

3. Eyupoglu B, Doganay M, Reis E, Yuksek YN, Kulacoglu S, Kama NI. The effects of scolocidal agents on hepatopancreaticobiliary system "An experimenal study". Turk J Gastroenterol 1999; 10: $280-6$.

Address for Correspondence / Yazışma Adresi: Dr. Serkan Teksöz, Department of General Surgery, Cerrahpaşa Faculty of Medicine, İstanbul University, İstanbul, Turkey Phone: +90 21241430 00/23002 E-mail: serkanteksoz@gmail.com 
4. Willatts SM, Radford S, Leitermann M. Effect of the antiendotoxic agent, taurolidine, in the treatment of sepsis syndrome: a placebocontrolled, double-blind trial. Crit Care Med 1995; 23: 1033-9. [CrossRef]

5. Gong L, Greenberg HE, Perhach JL, Waldman SA, Kraft WK. The Pharmacokinetics of Taurolidine Metabolites in Healthy Volunteers. Clin Pharmacol 2007; 47; 697-703. [CrossRef]

6. Browne MK, Pharmacological and clinical studies on Taurolin. In: Bruckner WL, Pfirrmann RW, eds. A New Concept in Antimicrobial Chemotherapy for Surgical Infection, Baltimore: Urban \& Schwarzenberg, 1985. 51.

7. Browne MK. The treatment of peritonitis by an antiseptic-Taurolin. Pharmatherapeutica 1981; 2: 517-22.

8. Blenkharn JJ. Sustained anti-adherence activity of taurolidine (Taurolin) and noxythiolin (Noxyflex S) solutions. J Pharm Pharmacol 1988; 40: 509-11. [CrossRef]
9. Gorman SP, McCafferty DF, Woolfson AD, Jones DS. Electron and light microscope observations of bacterial cell surface effects due to taurolidine treatment. Lett Appl Microbiol 1987; 4: 103-9. [CrossRef]

10. Monson JR, Ramsey PS, Donohue JH. Taurolidine inhibits tumor necrosis factor (TNF) toxicity: new evidence of TNF and endotoxin synergy. Eur J Surg Oncol 1993; 3: 226-31.

11. Watson RW, Redmond HP, McCarthy J, Bouchier-Hayes D. Taurolidine, an antilipopolysaccharide agent, has immunoregulatory properties that are mediated by amino acid taurine. J Leukoc Biol 1995; 58: 299-306.

12. Leithauser ML, Rob PM, Sack K. Pentoxifylline, cyclosporine A and taurolidine inhibit endotoxin-stimulated tumor necrosis factoralpha production in rat mesangial cell cultures. Exp Nephrol 1997; 1: 100-4. 